\title{
Relationship of Sweetpotato Yield and Quality to Amount of Irrigation
}

\author{
Paul G. Thompson \\ Department of Horticulture, Mississippi State University, P. 0. Drawer \\ T, Mississippi State, MS 39762
}

\author{
Doyle A. Smittle and Melvin R. Hall \\ Department of Horticulture, University of Georgia Coastal Plain \\ Experiment Station, Tifton, GA 31793
}

Additional index words. Ipomoea batatas, soil oxygen, storage loss, sugar content

\begin{abstract}
A line-source irrigation design was used to provide continuously increasing amounts of irrigation at each application to sweetpotato [Ipomoea batatas (L.) Lam]. Marketable yields increased with applied irrigation amounts until a total water application of $76 \%$ of pan evaporation $\left(E_{\text {pan }}\right)$ was reached and then decreased rapidly with applied irrigation amounts. Weight loss and decay of roots during storage showed quadratic responses to irrigation amounts and were minimal at the irrigation level of maximum yields. Contents of dextrins and maltose increased with irrigation amounts. Glucose content was maximum at a total water amount of $94 \% \mathrm{E}_{\mathrm{pan}}$ and fructose content decreased with increased amounts of irrigation. Sensory ratings for appearance, flavor, texture, and preference, and objective color measurements of cooked flesh also reached their highest values near the irrigation amount of maximum yield.
\end{abstract}

Yields of sweetpotatoes have been increased by irrigation in humid climates (Hammett et al., 1982; Hernandez et al., 1965; Jones, 1961; Lambeth, 1956; Peterson, 1961) in investigations designed to determine frequency of needed irrigation. Irrigation reduced percent dry matter, carotenoid content, and protein content of storage roots, but did not affect firmness, fiber content, or root splitting (Constantin et al., 1974; Hammett et al., 1982). Kattan et al. (1958) found maintaining available soil moisture above $50 \%$ increased enzymatic discoloration in canned roots.

Research on the effects of water application amounts at each irrigation is limited for sweetpotato. Lambeth (1956) irrigated to maintain available soil moisture above $40 \%$ of field capacity measured at $0.6,0.9$, or 1.2 $\mathrm{m}$. The highest yield resulted from maintaining available moisture above $40 \%$ to a depth of $0.6 \mathrm{~m}$. Weekly applications of 25 $\mathrm{mm}$ of water increased yields over no irrigation, but a weekly amount of $38 \mathrm{~mm}$ did not increase-yield further (Peterson, 1961). Evaporative demand was not reported in the experiments by Lambeth (1956) or Peterson (1961). To our knowledge, storage root quality responses to irrigation amounts have not been reported.

Response to higher amounts of irrigation might depend on increased fertilizer amounts, since $\mathrm{N}$ and $\mathrm{K}$ are used and lost more rapidly with increased moisture. Peterson (1961) compared amounts (in $\mathrm{kg} \cdot \mathrm{ha}^{-1}$ ) of $24 \mathrm{~N}-31 \mathrm{P}-$

\footnotetext{
Received for publication 19 Feb. 1991. Mississippi Agricultural and Forestry Experiment Station Article no. J-7706. The cost of publishing this paper was defrayed in part by the payment of page charges. Under postal regulations, this paper therefore must be hereby marked advertisement solely to indicate this fact.
}

$117 \mathrm{~K}$ to $40 \mathrm{~N}-53 \mathrm{P}-201 \mathrm{~K}$ in combination with weekly irrigations of 25 and $38 \mathrm{~mm}$ and found no yield difference attributable to the amount of fertilizer applied.

Yields of various crops have been similar over a range of irrigation depths (Braunworth and Mack, 1987; Stewart et al., 1977; Vaux and Pruitt, 1983) and the same may be true for sweetpotatoes. There is a need to more precisely quantify the effects of irrigation amounts to determine the level of irrigation needed for optimum yields and quality. In this experiment, continuously increasing amounts of irrigation were applied with several levels of fertilizer at two locations. The objective was to determine optimum irrigation depths at each location for yield of sweetpotato and if increased amounts of fertilizer were needed. An initial estimate of storage and quality responses to the amount of irrigation was made at one location.

Experiments were conducted in 1987 on a Bude silt loam soil (fine, mixed, thermic, Glossaquic Fraguidalf) at Pontotoc, Miss., and on a Tifton loamy sand soil (fine loamy, siliceous, thermic, Plinthitic Paleuidult) at Tifton, Ga. Available water-holding capacities of the soils were 156 and $89 \mathrm{~mm} \cdot \mathrm{m}^{-1}$ at Pontotoc and Tifton, respectively. Optimum production practices most commonly used in the area near each experimental location were employed. Fertilizer was applied according to extension service recommendations based on soil test results. At Pontotoc, fertilizer was broadcast and incorporated at transplanting to supply 0,50 , and $186 \mathrm{~kg}$ of $\mathrm{N}, \mathrm{P}$, and $\mathrm{K} / \mathrm{ha}$, respectively. Plots at Tifton received 30,26 , and $75 \mathrm{~kg}$ of $\mathrm{N}, \mathrm{P}$, and $\mathrm{K} / \mathrm{ha}$, respectively, applied in a band to each side of the row at transplanting.

Cultivars used were those grown most extensively in each state. 'Centennial' plants were transplanted to field plots 20 May at
Pontotoc in rows $1 \mathrm{~m}$ apart with plants spaced at $0.36 \mathrm{~m}$. 'Jewel' plants were transplanted 1 June at Tifton to rows $1.4 \mathrm{~m}$ apart with plants also spaced at $0.36 \mathrm{~m}$. Following transplanting, $13 \mathrm{~mm}$ of water was applied by sprinkler irrigation for plant establishment at both locations.

A line-source irrigation design with four replications was used (Hanks et al., 1976). The line-source system consisted of a single sprinkler irrigation line through the center of the experimental area and provided for a continuous decrease in the amounts of water applied to plots perpendicular to the irrigation line as distance from the line increased. Irrigation plots were two rows wide $(1.0 \mathrm{~m}$ between rows) and $18 \mathrm{~m}$ long at Pontotoc, and single rows $1.4 \mathrm{~m}$ apart by $12 \mathrm{~m}$ long at Tifton. Due to plot width, there were eight levels of irrigation at Pontotoc and 11 at Tifton.

Irrigations were applied during periods of no wind movement to prevent distortion of water application patterns and were made mostly between 9:00 PM and 5:00 AM. Rain gauges were placed in the center of each irrigation level at six equidistant linear spacings to measure the amounts of water applied. Observations during irrigations confirmed that no water runoff occurred.

Irrigation was scheduled based on evaporation from a U.S. Weather Bureau Type A pan $\left(\mathrm{E}_{\mathrm{pun}}\right)$. Beginning 11 days after transplanting, irrigation water was applied at Pontotoc and Tifton when $\mathrm{E}_{\text {pan }}$ exceeded rainfall by 50 and $25 \mathrm{~mm}$, respectively. Since no information was available on irrigation amounts, the same levels were used at both locations and were selected to be certain to include amounts above and below a likely optimum. The quantity of water applied to the intermediate irrigation rate at both locations was $40 \%$ of $\mathrm{E}_{\text {pan }}$ beginning 11 days after transplanting and was increased $2.4 \%$ daily to $120 \%$ of $\mathrm{E}_{\mathrm{pan}}$ on day 44 . The amount of water applied in each irrigation was constant at $120 \% \mathrm{E}_{\mathrm{pun}}$ from day 44 until harvest.

Previous fertilization results (unpublished data) showed that only $\mathrm{N}$ was leached from the Pontotoc soil, but increased levels of all elements might be needed for maximum yields at Tifton. Split fertilizer applications were included to more uniformly supply needed elements and counteract leaching with higher water applications. Fertilizer treatments were 0,45 , and $90 \mathrm{~kg} \mathrm{~N} / \mathrm{ha}$ at Pontotoc. The intermediate amount was applied in one application at transplanting. One-half of the 90 $\mathrm{kg} \cdot \mathrm{ha}^{-1}$ was applied at transplanting and the remaining half was sidedressed 60 days later. At Tifton, transplant fertilizer levels $\left(\mathrm{kg} \cdot \mathrm{ha}^{-1}\right)$ of $30 \mathrm{~N}-26 \mathrm{P}-75 \mathrm{~K}$ were augmented by $0 \mathrm{~N}$ $0 \mathrm{P}-0 \mathrm{~K}, 30 \mathrm{~N}-26 \mathrm{P}-75 \mathrm{~K}$, or $60 \mathrm{~N}-52 \mathrm{P}-150 \mathrm{~K}$ as sidedressed applications 30 days later. Investigations to determine needed amounts by element followed if yield responses to increased amounts of the complete fertilizer were observed. Fertilizer treatments were applied in randomized strips across irrigation levels and were $6 \mathrm{~m}$ long at both locations.

Storage roots were harvested and graded 15 Sept. at Pontotoc and 5 Oct. at Tifton. 
Table 1. Yield responses of sweetpotatoes to the amount of irrigation at Pontotoc, Miss., and Tifton, $\mathrm{Ga}$.

\begin{tabular}{|c|c|c|c|c|c|}
\hline \multicolumn{2}{|c|}{ Water supplied } & \multirow{2}{*}{\multicolumn{4}{|c|}{ Yield $\left(t \cdot h a^{-1}\right)$}} \\
\hline \multirow{2}{*}{$\begin{array}{l}\text { Irrigation }{ }^{z} \\
\text { (mm) }\end{array}$} & \multirow{2}{*}{$\begin{array}{c}\text { Totaly }^{y} \\
(\%)\end{array}$} & & & & \\
\hline & & Marketable & U.S. No. 1 & Canner & Jumbo \\
\hline \multicolumn{6}{|c|}{ Pontotoc (Centennial) } \\
\hline 708 & 147 & 11.9 & 1.9 & 9.9 & 0.1 \\
\hline 614 & 134 & 12.6 & 1.3 & 11.2 & 0.1 \\
\hline $495^{x}$ & 118 & 16.4 & 2.7 & 13.6 & 0.1 \\
\hline 381 & 103 & 17.7 & 3.1 & 14.5 & 0.1 \\
\hline 277 & 89 & 21.8 & 6.7 & 14.7 & 0.4 \\
\hline 178 & 76 & 32.8 & 16.0 & 16.0 & 0.8 \\
\hline 84 & 63 & 30.1 & 12.9 & 16.6 & 0.6 \\
\hline 0 & 52 & 26.7 & 11.0 & 15.2 & 0.5 \\
\hline Linear & & $* *$ & $* *$ & $* *$ & $* *$ \\
\hline Quadratic & & $* *$ & $* *$ & $* *$ & $* *$ \\
\hline \multicolumn{6}{|c|}{ Tifton (Jewel) } \\
\hline 711 & 158 & 23.6 & 4.4 & 19.1 & 0.1 \\
\hline 642 & 148 & 25,8 & 4.9 & 20.7 & 0.2 \\
\hline 544 & 134 & 22.2 & 7.2 & 14.9 & 0.1 \\
\hline 460 & 122 & 27.8 & 10.6 & 17.1 & 0.1 \\
\hline $385^{x}$ & 111 & 24.5 & 9.1 & 15.1 & 0.3 \\
\hline 325 & 103 & 27.7 & 11.8 & 15.7 & 0.2 \\
\hline 266 & 94 & 29.6 & 16.6 & 11.9 & 1.1 \\
\hline 193 & 84 & 32.6 & 21.3 & 9.3 & 2.0 \\
\hline 127 & 74 & 36.6 & 24.0 & 7.8 & 4.8 \\
\hline 68 & 66 & 34.7 & 22.6 & 5.2 & 6.9 \\
\hline 4 & 57 & 22.3 & 13.6 & 3.4 & 5.3 \\
\hline Linear & & $* *$ & $* *$ & $* *$ & $* *$ \\
\hline Quadratic & & ** & ** & ** & $* *$ \\
\hline
\end{tabular}

IIrigation water applied in nine and 13 applications at Pontotoc and Tifton, respectively. All plots received $13 \mathrm{~mm}$ of irrigation after transplanting plus 376 and $380 \mathrm{~mm}$ of rainfall at Pontotoc and Tifton, respectively.

yTotal expressed as a percentage of pan evaporation.

xAmount based on pan evaporation, other rates due to gradient produced by the line-source irrigation system.

****Significant at $P=0.05$ and 0.01 , respectively.

Table 2. Curing and storage responses of 'Yewel' sweetpotalues to total anount of water supplied at Tifton, Ga.

\begin{tabular}{|c|c|c|c|c|c|c|}
\hline \multirow{3}{*}{$\begin{array}{c}\text { Total amount } \\
\text { of water } \\
(\%)\end{array}$} & \multirow{2}{*}{\multicolumn{2}{|c|}{ Curing $\operatorname{loss}^{y}(\%)$}} & \multirow{2}{*}{\multicolumn{2}{|c|}{ Storage loss ${ }^{x}(\%)$}} & \multicolumn{2}{|c|}{ Dry wt (\%) } \\
\hline & & & & & \multirow{2}{*}{$\begin{array}{c}\text { After } \\
\text { harvest }\end{array}$} & \multirow{2}{*}{$\begin{array}{c}\text { After } \\
\text { storage }\end{array}$} \\
\hline & $\mathrm{Wt}$ & Decay & Wt & Decay & & \\
\hline 158 & 11.7 & 19.3 & 21.4 & 33.5 & 25.6 & 26.8 \\
\hline 134 & 13.0 & 25.2 & 21.5 & 24.8 & 23.6 & 25.3 \\
\hline 111 & 10.3 & 0.0 & 13.9 & 6.6 & 23.2 & 24.4 \\
\hline 94 & 8.6 & 14.4 & 10.1 & 5.2 & 22.6 & 23.3 \\
\hline 74 & 8.0 & 0.0 & 10.5 & 2.5 & 22.6 & 22.7 \\
\hline 57 & 8.0 & 5.4 & 14.8 & 4.1 & 21.2 & 22.2 \\
\hline Linear & $* *$ & $*$ & $* *$ & $* *$ & $* *$ & $* *$ \\
\hline Quadratic & NS & NS & $* *$ & $* *$ & $*$ & $*$ \\
\hline
\end{tabular}

${ }^{2}$ Total expressed as percentage of pan evaporation.

yExpressed as percentage of precured weight.

${ }^{x}$ Expressed as percentage of prestorage weight.

NS,***Nonsignificant or significant at $P=0.05$ and 0.01 , respectively.

Quality and weight loss measurements were made at Tifton. U.S. No. 1 roots from alternate irrigation treatments, beginning with the lowest level (see Table 1), were cured for 7 days at 30C and 90\% relative humidity (RH) and placed in storage at $16 \mathrm{C}$ and $80 \%$ RH. Flesh color and dry weights of raw 'Jewel' were determined before curing, after curing, and after 4 months of storage. Ten roots from each treatment were cut transversely immediately before color analyses with a colorimeter (Gardner x1-20 Tri-stimulus; Gardner/Neotec, Silver Spring, Md.) and standardized to a reference plate: $\mathrm{L}=$ $70.4, \mathrm{a}=23.9, \mathrm{~b}=9.3$. After color measurements, $10-\mathrm{mm}$ slices from each root were peeled and cut into $10-\mathrm{mm}$ dices before drying in a forced-air oven at $70 \mathrm{C}$ for $72 \mathrm{~h}$.

A $30-\mathrm{mm}$ transverse slice from each of the 10 roots was wrapped in aluminum foil and baked at 190C for $90 \mathrm{~min}$ and cooled. The baked flesh was macerated with a fork, mixed, and presented to a six-member trained sensory panel for evaluations of appearance, flavor, texture, and preference. About $75 \mathrm{~g}$ of the cooked tissue was placed in a $55-\mathrm{mm}$ diameter cup having an optical-glass bottom for color analyses. This sample was frozen for sugar analyses by high-pressure liquid chromatography (HPLC). For sugar analyses, $2.5 \mathrm{~g}$ of baked sweetpotato tissue was placed in a centrifuge tube, One gram of diatomaceous earth and $40 \mathrm{ml}$ of distilled water were added, mixed thoroughly, heated at $60 \mathrm{C}$ for $30 \mathrm{~min}$, cooled, and centrifuged at $11,000 \times g$ to separate particulate material. A $10-\mathrm{ml}$ aliquot of the supernatant was passed through a silica preparatory cartridge, with the first $5 \mathrm{ml}$ being discarded. A $20-\mu \mathrm{l}$ aliquot was used for analyses for glucose, fructose, maltose, and dextrins by HPLC.

The desired information from these experiments was the relationship of the amount of water to storage root yield and quality components. Therefore, yield and quality data were analyzed by regression (Chew, 1976; Little, 1978, 1981).

Amounts of water applied based on $\mathrm{E}_{\mathrm{par}}$ were similar for the two sites (Table 1), since $\mathrm{E}_{\mathrm{pan}}$ amounts were 747 and $700 \mathrm{~mm}$ during production of the sweetpotato crops at Pontotoc and Tifton, respectively. Nine irrigations were made at Pontotoc and 13 at Tifton $\mathrm{E}_{\mathrm{pan}}$ exceeded rainfall sufficiently for irrigations on days $11,47,56,64,69,81,90$, 96, and 107 after transplanting at Pontotoc and on days $31,36,42,46,50,55,60,67$, $71,83,87,91$, and 110 at Tifton. Total rainfall was also similar at the two locations, 376 and $380 \mathrm{~mm}$ at Pontotoc and Tifton, respectively. Total water amounts (irrigation + rainfall) ranged from $52 \%$ to $147 \%$ of $\mathrm{E}_{\text {pan }}$ at Pontotoc and from $57 \%$ to $158 \%$ of $\mathrm{E}_{\mathrm{pan}}$ at Tifton (Table 1).

Marketable, U.S. No. I, canner, and jumbo root yields showed strong quadratic changes with irrigation amounts at both locations (Table 1). Yields at Pontotoc were highes when total water applied to the 'Centennial' sweetpotatoes was $76 \%$ of $\mathrm{E}_{\mathrm{pan}}$. Marketable root yield was reduced slightly with total water amounts $<76 \%$ of $\mathrm{E}_{\mathrm{pan}}$, whereas total water amounts $>76 \%$ of $\mathrm{E}_{\mathrm{pan}}$ substantially reduced marketable yield. Most of the change in marketable yield of 'Centennial' roots was due to variations of U.S. No. 1 yield. Total water application at $76 \%$ of $\mathrm{E}_{\mathrm{pan}}$ produced U.S. No. 1 yields that were $45 \%$ higher than without irrigation, but irrigation applications that resulted in total water amounts of $147 \%$ of $\mathrm{E}_{\text {pan }}$ produced only $17 \%$ of the U.S. No. 1 yield produced without irrigation.

Yields of 'Jewel' sweetpotatoes at Tifton showed response trends to water application amounts that were similar to the Mississippi experiment, although marketable and U.S. No. 1 yield reductions with high irrigation amounts were not as great at Tifton as at Pontotoc. The greatest sensitivity to excess irrigation at Pontotoc is not attributable to the cultivar because 'Jewel' has been reported to be more sensitive to flood damage than 'Centennial' (Collins and Wilson, 1988).

Weight loss and decay during curing and storage of 'Jewel' roots showed strong responses to the total amount of water applied (Table 2). Weight loss and decay were high when total water received was $134 \%$ to $158 \%$ of $\mathrm{E}_{\text {. }}$. They were minimal at total water amounts of $74 \%$ to $94 \%$ of $\mathrm{E}_{\mathrm{pan}}$ and then increased at totals of $57 \%$ of $\mathrm{E}_{\mathrm{pan}}$. Dry weight increased with increased water quantities.

Glucose, fructose, maltose, and dextrins (three to five glucose units) represented 6\%, $4 \%, 65 \%$, and $25 \%$ of the total sugars, respectively, in baked 'Jewel' sweetpotatoes. 
Table 3. Effect of total amount of water supplied during production (at Tifton, Ga.) on sugar content and sensory evaluations of baked 'Jewel' sweetpotatoes after curing and storage.

\begin{tabular}{|c|c|c|c|c|c|c|c|c|c|}
\hline \multirow{2}{*}{$\begin{array}{c}\text { Total amount } \\
\text { of water } \\
(\%)\end{array}$} & \multicolumn{5}{|c|}{ Sugars (\%) } & \multicolumn{4}{|c|}{ Sensory rating ${ }^{\mathbf{x}}$} \\
\hline & Dextrins $^{y}$ & Maltose & Glucose & Fructose & Total & Appearance & Flavor & Texture & Preference \\
\hline 158 & 5.3 & 15.5 & 1.1 & 0.75 & 22.6 & 4.5 & 3.9 & 4.3 & 4.1 \\
\hline 134 & 5.8 & 14.7 & 1.2 & 0.80 & 22.5 & 5.6 & 4.7 & 5.1 & 4.9 \\
\hline 111 & 5.8 & 14.2 & 1.3 & 0.80 & 22.1 & 6.2 & 5.7 & 5.6 & 5.6 \\
\hline 94 & 5.3 & 13.1 & 1.5 & 0.89 & 20.8 & 6.5 & 5.9 & 6.2 & 5.9 \\
\hline 74 & 4.5 & 12.4 & 1.4 & 0.88 & 19.1 & 6.0 & 5.7 & 6.0 & 5.8 \\
\hline 57 & 5.1 & 12.4 & 1.4 & 0.98 & 19.8 & 5.6 & 5.6 & 5.8 & 5.7 \\
\hline Linear & $*$ & $* *$ & $*$ & $* *$ & $*$ & $*$ & $* *$ & $* *$ & $* *$ \\
\hline Quadratic & NS & NS & $*$ & NS & NS & $* *$ & $* *$ & $* *$ & $* *$ \\
\hline
\end{tabular}

Total expressed as percentage of pan evaporation.

yDextrins composed of three, four, and five glucose units.

×Sensory rating on a hedonic scale of 1 to $7 ; 1=$ disliked extremely and $7=$ liked extremely.

Ns.*,**Nonsignificant or significant at $P=0.05$ and 0.01 , respectively.

Table 4. Effect of total amount of water applied during production (at Tifton, Ga.) on flesh color of fresh, stored, and baked 'Jewel' sweetpotatoes.

\begin{tabular}{|c|c|c|c|c|c|c|}
\hline \multirow{3}{*}{$\begin{array}{c}\text { Total amount } \\
\text { of water } \\
(\%)\end{array}$} & \multicolumn{4}{|c|}{ Flesh color ${ }^{y}$} & & \\
\hline & \multicolumn{2}{|c|}{ After harvest ${ }^{w}$} & \multicolumn{2}{|c|}{ After storage } & \multicolumn{2}{|c|}{ Cooked color ${ }^{\mathrm{x}}$} \\
\hline & $\mathrm{L}$ & $a$ & $\mathrm{~L}$ & $\mathrm{a}$ & $\mathrm{L}$ & $a$ \\
\hline 158 & 68.3 & 29.3 & 69.0 & 29.2 & 39.8 & 16.3 \\
\hline 134 & 68.6 & 28.9 & 67.8 & 30.8 & 40.1 & 17.3 \\
\hline 111 & 67.4 & 29.1 & 67.5 & 31.5 & 40.1 & 18.2 \\
\hline 94 & 67.9 & 30.3 & 66.5 & 32.0 & 43.1 & 19.7 \\
\hline 74 & 68.1 & 29.6 & 67.1 & 31.0 & 45.8 & 19.4 \\
\hline 57 & 68.0 & 29.2 & 67.4 & 30.0 & 46.7 & 18.0 \\
\hline Linear & $*$ & NS & $*$ & NS & $*$ & $* *$ \\
\hline Quadratic & NS & $*$ & * & ** & NS & ** \\
\hline
\end{tabular}

2Total water amount expressed as a percentage of pan evaporation.

yColor measurement of sliced raw tissue.

*Color measurement of mashed cooked tissue after storage of roots.

${ }^{\text {w }} \mathrm{a}$ and $\mathrm{a}=$ colorimeter measurements of reflectance and red pigmentation, respectively.

Ns,****Nonsignificant or significant at $P=0.05$ and 0.01 , respectively.

The linear increase in total sugar concentration with increased water amounts was due to an increase of maltose and dextrin concentration from $17.5 \%$ of fresh weight with total water of $57 \% \mathrm{E}_{\mathrm{pm}}$ to $20.8 \%$ of fresh weight with total water of $158 \% \mathrm{E}_{\mathrm{pun}}$ (Table 3 ). The concentration of simple sugars, glucose and fructose, decreased from $2.4 \%$ of fresh weight with total water of $57 \% \mathrm{E}_{\mathrm{pan}}$ to $1.8 \%$ with $158 \% \mathrm{E}_{\mathrm{pan}}$.

The baked roots were rated highest for appearance, flavor, texture, and overall preference when total water applied was $94 \%$ of $\mathrm{E}_{\mathrm{pan}}$ (Table 3). Sensory ratings of sweetpotatoes receiving the most water were particularly low due to discoloration, poor flavor, and a sticky texture of the roots. Increased enzymatic discoloration has been observed upon heating sweetpotatoes from high-irrigation regimes (Kattan et al., 1958). In the objective color analyses, total reflectance (L) decreased for baked roots grown with increased amounts of water, and less intensity of red pigmentation (a) resulted with either high or low amounts of water (Table 4).

In contrast to most plants injured by flooding (Cannel1 et al., 1979; Letey et al. 1962a, 1962b; Wadman-van SchravendijK and van Andel, 1985), the plants receiving the highest amounts of water in these experiments appeared vigorous. This observation agrees with results reported by Chua and Kays (1981) that top growth was enhanced and storage root growth was retarded by low root-zone $\mathrm{O}_{2}$ concentration. However, low root-zone
$\mathrm{O}_{2}$ concentration cannot be assigned as the cause of reduced root growth in this experiment, because soil $\mathrm{O}_{2}$ content was not measured.

None of the yield or quality characteristics of 'Centennial' or 'Jewel' were affected by application of a fertilizer. These results indicated that adequate nutrients are supplied by the basic fertilization level of 0,50 , and $186 \mathrm{~kg}$ of N, P, and K/ha to a Bude silt loam and 30,26 , and $75 \mathrm{~kg}$ of $\mathrm{N}, \mathrm{P}$, and $\mathrm{K} / \mathrm{ha}$ to a Tifton loamy sand when these soils are used for intensive crop production.

We have shown that yield and quality of sweetpotatoes are influenced by the amount of irrigation. Irrigation to supplement rainfall in providing total amounts of water equivalent to $\approx 75 \%$ of $\mathrm{E}_{\mathrm{pan}}$ produced maximum yields of sweetpotatoes grown on silt loam and loamy sand soils at Pontotoc and Tifton, respectively. Irrigation to provide total amounts of water equivalent to $75 \%$ to $95 \%$ of $\mathrm{E}_{\mathrm{pan}}$ resulted in minimum loss during storage and maximum quality of cooked sweetpotatoes after storage. The silt loam soil was more susceptible to excessive water application than the loamy sand.

\section{Literature Cited}

Braunworth, W.S., Jr., and H.J. Mack. 1987. Effect of deficit irrigation on yield and quality of sweet corn. J. Amer. Sot. Hort. Sci. 112:3235 .

Cannell, R.Q., K. Gales, R.W. Snaydon, and B.A. Suhail. 1979. Affects of short-term water $\log$ - ging on the growth and yield of peas. Ann. Applied Biol. 93:327-335.

Chew, V. 1976. Comparing treatment means: A compendium. HortScience 11:348-357.

Chua, L.K. and S.J. Kays. 1981. Effect of soil oxygen concentration on sweet potato storage root induction and/or development. HortScience 16:71-73.

Collins, W.W. and L.G. Wilson. 1988. Reaction of sweet potatoes to flooding. HortScience 23:1079.

Constantin, R.J., T.P. Hernandez, and L.G. Jones. 1974. Effect of irrigation and nitrogen fertilization on quality of sweet potatoes. J. Amer. Sot. Hort. Sci. 99:308-310.

Hammett, H.L., R.J. Constantin, L.G. Jones, and T.P. Hernandez. 1982. The effect of phosphorus and soil moisture levels on yield and processing quality of 'Centennial' sweet potatoes. J. Amer. Sot. Hort. Sci. 107:119-122.

Hanks, R.J., J. Keller, V.P. Rasmussen, and G.D. Wilson. 1976. Line source sprinkler for continuous variable irrigation-crop production studies. Soil Sci. Sot. Amer. Proc. 40:426-429.

Hernandez, T.P., T.P. Hernandez, J.C. Miller, and L.G. Jones. 1965. The value of irrigation in sweet potato production in Louisiana. Louisiana Agr. Expt. Sta. Bul. 607.

Jones, S.T. 1961. Effect of irrigation at different levels of soil moisture on yield and evapotranspiration rate of sweet potatoes. Proc. Amer. Sot. Hort. Sci. 77:458-462.

Kattan, A., B.D. Horton, and J.N. Moore. 1958. Effect of supplemental irrigation on yield and quality of two vegetable crops. Arkansas Agr. Expt. Sta. Farm Res. 7(3):3.

Lambeth, V.N. 1956. Studies in moisture relationships and irrigation of vegetables. Missouri Agr. Expt. Sta. Res. Bul. 605.

Letey, J., L.H. Stolzy, N. Valoras, and T.E. Szuszkiewicz. 1962b. The influence of oxygen diffusion rate on sunflower growth at various soil and air temperatures. Agron. J. 54:316319.

Letey, J., L.H. Stolzy, N. Valoras, and T.E. Szuszkiewicz. 1962b. Influence of soil oxygen on growth and mineral concentration of barley. Agron. J. 54:538-540.

Little, T.M. 1978. If Galileo published in HortScience. HortScience 13:504-506.

Little, T.M. 1981. Interpretation and presentation of results. HortScience 16:637-640.

Peterson, L.E. 1961. The varietal response of sweet potatoes to changing levels of irrigation, fertilizer and plant spacing. Proc. Amer. Sot. Hort. Sci. 77:452-457.

Stewart, J.I., R.M. Hagan, W.O. Pruitt, R.E. Danielson, W.T. Franklin, R.J. Hanks, J.P. Riley, and E.B. Jackson. 1977. Optimizing crop production through control of water and salinity 
levels in the soil. Utah Water Research Lab., College of Engineering, Utah State Univ., Logan. PRWG151-1.

Vaux, H.J. and W.O. Pruitt. 1983. Crop water production functions, p. 61-97. In: D. Hillel (ed.). Advances in irrigation. vol. 2. Academic, New York.

Wadman-van Schravendijk, H. and O.M. van An- del. 1985. Interdependence of growth, water relations and abscisic acid level in Phaseolus vulgaris during waterlogging. Physiol. Plant. $63: 215-220$.

HORTSCIENCE 27(1):26-27. 1992.

\title{
Two Putative Cryoprotectants do not Provide Frost and Freeze Protection in Tomato and Pepper
}

\author{
Katharine B. Perry, ${ }^{1}$ A. Richard Bonanno ${ }^{2}$, and David W. Monks \\ Department of Horticultural Science, North Carolina State University, \\ Raleigh, NC 27695-7609
}

Additional index words.Lycopersicon esculentum, Capsicum annuum, Solanaceae, tolerance, antitranspirant

\begin{abstract}
A commercially available cryoprotectant $(50 \%$ propylene block copolymer of polyoxyethylene, $50 \%$ propylene glycol; trade name FrostFree) and an antitranspirant $(96 \%$ di-1-p-menthene, i.e., pinolene, a terpenic polymer, $4 \%$ inert; trade name Vapor Gard) were evaluated for their ability to protect 'Pik Red' tomato (Lycopersicon esculentum Mill.) and 'Keystone Resistant Giant \#3' pepper (Capsicum annuum L.) plants during frost and freeze occurrences in the field. Tests were conducted during four spring and two fall seasons. Protection from these products was not observed under field conditions when minimum air temperature reached $-3.5 \mathrm{C}$ and $-1.0 \mathrm{C}$ on separate occasions. Yields for treated and untreated plants were similar. Neither cryoprotectant injured the foliage in the absence of cold events.
\end{abstract}

High prices for early season produce encourage vegetable growers to plant as soon as soils have warmed. Although knowledge of the average last frost or freeze date and the short-term temperature forecast can be used in making planting decisions to avoid frost or freeze damage, instances do occur when temperatures drop to damaging levels after transplanting. Irrigation systems designed to meet drought needs are not always suitable for frost protection, and traditional heating systems cannot be justified economically. Therefore, economically feasible alternative frost protection options are needed. Several chemical products have been marketed and promoted as inexpensive and effective in preventing crop damage from frost or freeze.

Rieger (1989) conducted an extensive review of chemicals used to increase cold hardiness and delay spring budbreak in horticultural crops. Previous work has shown

Received for publication 19 Dec. 1990. Accepted for publication 15 July 1991. The use of trade names in this publication does not imply endorsement by the NCARS of the products named, nor criticism of similar ones not mentioned. The cost of publishing this paper was defrayed in part by the payment of page charges. Under postal regulations, this paper therefore must be hereby marked advertisement solely to indicate this fact.

'Associate Professor.

${ }^{2}$ Associate Professor. Currently Senior Extension Specialist, Dept. Plant and Soil Sci., Univ. Mass., Amherst, MA 01003.

${ }^{3}$ Assistant Professor, that antitranspirants did not decrease freeze damage to developing peach (Prunus persica Batsch) fruits (Matta et al., 1987; Rieger and Krewer, 1988), young citrus trees (Burns, 1970, 1973) or tropical foliage plants (Fitzpatrick et al., 1986). Rieger and Krewer (1988) reported that Protec (Delacar Corp., Tavares, Fla.), an antitranspirant, increased mortality of almond and plum blossoms exposed to $-4.4 C$. Call and Seeley (1989) reported that the antitranspirant Wilt-Pruf (Wilt Products, Greenwich, Conn.) significantly reduced the T50 for 'Johnson Elberta' peach flower buds, but through delay of dehardening, which could not be applied to vegetable transplants. Previous work on the croyoprotectant FrostFree (Plant Products, Vero Beach, Fla.) found it ineffective in increasing survival of ovaries of various Prunus spp. (Matta et al., 1987; Rieger and Krewer, 1988). Vapor Gard (Miller Chemical and Fertilizer, Hanover, Pa.), an antitranspirant, is sold to retard transpiration and maintain healthy foliage, but the label also specifies that it can be used to protect from cold dessication. However, we found no refereed results of using these materials on vegetable crops.

The objective of this study was to evaluate these two commercially available materials for frost and freeze protection of pepper and tomato transplants under field conditions. FrostFree is $50 \%$ propylene block copolymer of polyoxyethyene, $50 \%$ propylene glycol, and Vapor Gard is $96 \%$ di-1-p-menthene (i.e., pinolene, a terpenic polymer, $4 \%$ inert). Use of a field study over one in a controlled en- vironment was justified because antitranspirants are hypothesized to act as barriers to external nucleators (Levitt, 1980). The antitranspirant film on the surface of the leaves is thought to impede the frost that forms on the surface from providing a nucleator for water inside the plant. Inability to make frost form on the plants in a controlled chamber negates the use of such a chamber in testing the Vapor Gard material.

'Pik Red' tomatoes and 'Keystone Resistant Giant \#3' peppers were seeded in the greenhouse and grown to transplant stage (two ditrue leaves). The plants were fertilized twice in the greenhouse with $20 \mathrm{~N}-20 \mathrm{P}-20 \mathrm{~K}$ fertilizer (3.75 g/liter Peters Fertilizer Products, W.R. Grace, Fogelsville, Pa.), No preconditioning by water or fertilizer reduction was carried out.

Plants were transplanted at the Central Crops Research Station near Clayton, N.C., on a Typic Paleudult with $0.3 \%$ humic matter and $\mathrm{pH}$ 5.3. A randomized complete-block design with four replicates was used. Transplanting occurred as early as possible in advance of the average last frost date for Clayton (7 Apr., SD $=12$ days). Pepper plants were spaced $30 \mathrm{~cm}$ and tomato plants $45 \mathrm{~cm}$ in 1.5 -m-wide ridges. Each plot consisted of one row $4.5 \mathrm{~m}$ long. The Fall 1987 test was initiated when a frost was forecast within the next 5 days. The Fall 1988 test was initiated to precede the average first fall frost by one SD (25 Oct., SD $=10$ days).

FrostFree was evaluated in the springs of 1987-90 and in Fall 1987 and 1989. Six treatments were imposed during 1987-89, with applications to the plants of $\left(\mathrm{kg} \cdot \mathrm{ha}^{-1}\right)$ : 1) 0.7 one day before transplanting, 2) 0.7 immediately after transplanting, 3) and 4) 0.7 or 1.3 when a frost or freeze was imminent (usually the day before), 5) $0.3 \mathrm{im}$ mediately after transplanting and 0.3 repeated when a frost or freeze was imminent and 6) no cryoprotectant (left dry). In 1990, a control or one of two treatments, $1.1 \mathrm{~kg} \cdot \mathrm{ha}^{-1}$ applied to the plants either 1 day before transplanting or when frost or freeze was immiment, was used. Vapor Gard was evaluated in Spring 1989 and 1990 and Fall 1989. The two treatments consisted of a pretransplant application to the plants at $1.0 \mathrm{~kg} \cdot \mathrm{ha}$ and a $1.0 \mathrm{~kg} \cdot \mathrm{ha}^{-1}$ application when a frost or freeze was imminent and a control that was left dry. Manufacturer's guidelines for FrostFree specify reapplication every 10 days. This necessitated multiple applications in Fall 1989. FrostFree and Vapor Gard were applied with a $\mathrm{CO}$, backpack sprayer pressurized at $276 \mathrm{kPa}$ to deliver 375 liters of spray solution/ha.

Air temperature in the field was measured by three Taylor maximum-minimum self- 